ISSN 0515-0361

Volume 30, No. 1

May 2000
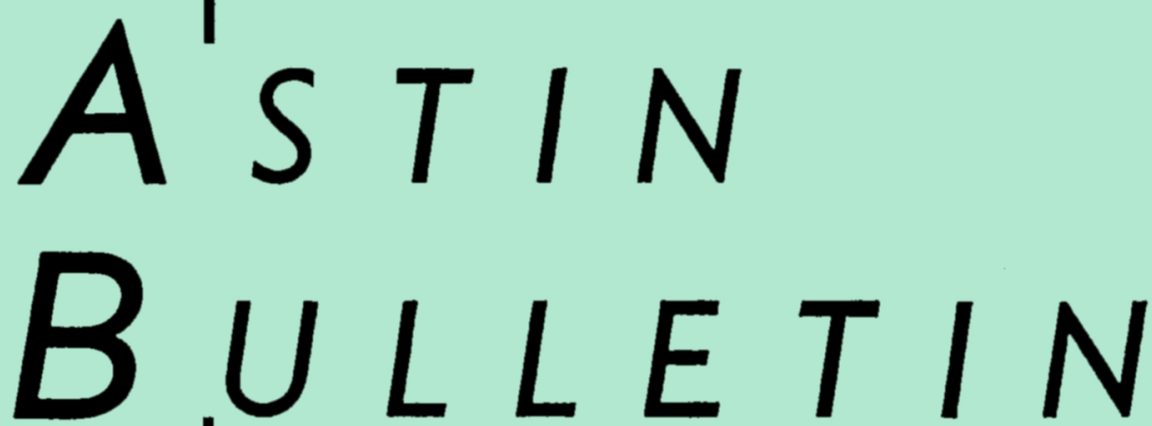

The Journal of the ASTIN and AFIR Sections of the International Actuarial Association

\title{
Contents
}

\section{EDITORIAL CHANGE}

\section{ARTICLES}

EDITOR :

Paul Embrechts

Co-EdrTors:

Andrew Cairns

René Schnieper

EdTORIAL BOARD :

D. Promislow, V.R. YounG

Equity and Exact Credibility

J.-L. WANG

A Note on Christofides' Conjecture Regarding

Wang's Premium Principle

A. CAIRnS

Some Notes on the Dynamics and Optimal Control of

Stochastic Pension Fund Models in Continuous Time

R. VERNIC

A Multivariate Generalization of the Generalized Poisson Distribution

A. Macdonald, D. Pritchard

A Mathematical model of Alzheimer's Disease and the Apoe Gene

Marc Goovaerts

Mary Hardy

Ole Hesselager

Christian Hipp

Jacques Janssen

William S. Jewell

Jean Lemaire

B. SUNDT

On Multivariate Vernic Recursions

\section{WORKSHOP}

G. DeElstra

Long-Term Returns in Stochastic Interest Rate Models:

Applications

J.F. WALHIN, J. PARIS

Recursive Formulae for Some Bivariate Counting

Distributions Obtained by the Trivariate Reduction Method

S.H. Cox, J.R. Fairchild, H.W. Pedersen Economic Aspects of Securitization of Risk

R. SCHNIEPER

Portfolio Optimization

Robert Reitano 


\section{EDITORIAL POLICY}

ASTIN BULLETIN started in 1958 as a journal providing an outlet for actuarial studies in non-life insurance. Since then a well-established non-life methodology has resulted, which is also applicable to other fields of insurance. For that reason ASTIN BULLETIN has always published papers written from any quantitative point of view - whether actuarial, econometric, engineering, mathematical, statistical, etc. - attacking theoretical and applied problems in any field faced with elements of insurance and risk. Since the foundation of the AFIR section of IAA, i.e. since 1988, ASTIN BULLETIN has opened its editorial policy to include any papers dealing with financial risk.

We especially welcome papers opening up new areas of interest to the international actuarial profession. ASTIN BULLETIN appears twice a year (May and November), each issue consisting of at least 80 pages.

Details concerning submission of manuscripts are given on the inside back cover.

\section{MEMBERSHIP}

ASTIN and AFIR are sections of the International Actuarial Association (IAA). Membership is open automatically to all IAA members and under certain conditions to non-members also. Applications for membership can be made through the National Correspondent or, in the case of countries not represented by a national correspondent, through a member of the Committee of ASTIN.

Members of ASTIN receive ASTIN BULLETIN free of charge. As a service of ASTIN to the newly founded section AFIR of IAA, members of AFIR also receive ASTIN BULLETIN free of charge.

\section{SUBSCRIPTION AND BACK ISSUES}

ASTIN BULLETIN is published and printed for ASTIN by Ceuterick s.a., Brusselsestraat 153, B-3000 Leuven, Belgium-E-mail: info@ceuterick.be, fax: + 3216204533

All queries and communications concerning subscriptions, including claims and address changes, and concerning back issues should be sent to Ceuterick.

The current subscription or back issue price per volume of 2 issues including postage is BEF 2500.

Back issues up to issue 10 ( $=$ up to publication year 1979) are available for half of the current subscription price.

\section{INDEX TO VOLUMES 1-27}

The Cumulative Index to Volumes 1-27 is also published for ASTIN by Ceuterick at the above address and is available for the price of BEF 400 . 